\title{
PENGARUH TAX AVOIDANCE, CORPORATE GOVERNANCE INDEX, KEBIJAKAN HUTANG DAN GROWTH OPPORTUNITY TERHADAP NILAI PERUSAHAAN
}

Muhammad Ridho

Universitas Islam Nahdlotul Ulama

Muhammadridho80@unisnu.ac.id

\begin{abstract}
ABSTRAK
Penelitian in dilakukan untuk menguji pengaruh Tax Avoidance, Corporate Governance Index, Kebijakan Hutang dan Growth Opportunity terhadap Nilai Perusahaan pada perusahaan yang terdaftar di Corporate Governance Perception Index. Penelitian ini menggunakan data sekunder yaitu data kuantitatif, populasi dalam penelitian ini berjumlah 72 perusahaan yang sudah terdaftar di CGPI dan BEI. Teknik pengambilan sampel dengan metode purposive sampling dan data diperoleh sesuai kriteria yaitu berjumlah 17 perusahaan. Penelitian dibatasi oleh perusahaan perbankan dan manufaktur pada tahun2015-2017. Hasil penelilian menunjukkan bahwa Tax Avoidance dan Corporate Governance Index, berpengaruh signifikan terhadap nilai perusahaan, sedangkan Kebijakan Hutang dan Growth Opportunity tidak berpengaruh signifikan terhadap nilai perusahaan. Variabel Tax Avoidance, Corporate Governance Index, Kebijakan Hutang dan Growth Opportunity mempengaruhi variabel Nilai Perusahaan sebanyak 24,5\% sedangkan sisanya dipengaruhi faktor lain yang tidak diteliti dalam penelitian ini.

Kata kunci: Tax Avoidance, Corporate Governance Index, Kebijakan Hutang, Growth Opportunity dan Nilai perusahaan.
\end{abstract}

\section{PENDAHULUAN}

Peningkatan nilai perusahaan yang tinggi merupakan tujuan jangka panjang yang ingin dicapai perusahaan yang akan tercermin dari harga pasar sahamnya karena para investor menilai dan mengamati melalui pergerakan harga saham pada perusahaan yang diterbitkan dibursa efek Indonesia untuk perusahaan yang sudah go public. Membeli saham dengan harga tinggi terhadap perusahaan yang dinilai tinggi akan diminati karena investor akan lebih berani dalam membeli saham tersebut (Retno, 2012). Tujuan perusahaan salah satunya peningkatan nilai perusahaan yag dapat dicapai melalui fungsi manajemen, suatu keputusan yang diambil akan berpengaruh terhadap keputusan yang lain dan juga akan berdampak pada nilai perusahaan (Wahyudi dan Pawestri, 2006 ). Ada beberapa keputusan manajemen yang berdampak terhadap nilai perusahaan yaitu keputusan dalam penghindaran pajak, keputusan menjalankan perusahaan yang berprinsip GCG dan keputusan menentukan 
kebijakan hutang dan juga pada pertumbuhan kesempatan dinilai berdampak terhadap nilai perusahaan tersebut.

Tax avoidance adalah upaya-upaya atau strategi yang masih dalam ketentuan peraturan undang-undang perpajakan yang digunakan untuk memperkecil jumlah pajak yang terutang (Chasbiandi, 2012). Tax avoidance dapat mencerminkan adanya kepentingan kepemilikan manajer dengan melakukan manipulasi atau modivikasi laba yang menimbulkan laporan keuangan perusahaan tidak sesuai dengan laporan keuangan yang asli, dan ini akan menjadi informasi bagi investor juga. Dengan hal tersebut investor dapat mejadi ragu untuk membeli saham perusahaan tersebut karena nilai perusahaan rendah.

Good corporate governance merupakan upaya bagi perusahaan dalam mengelola sebuah resiko signifikan yang bergunan untuk memenuhi kebutuhan perusahaan dengan carapengamanan asset dan meningkatkan nilai investasi pada pemegang saham jangka waktu yang panjang (Effendi, 2009). Hal tersebut mempunyai nilai positif karena akan menumbuhkan keyakinan bagi pemegang saham dan juga kepada investor bahwa manajer akan memberikan keuntungan bagi mereka. Karena manajer akan memberikan yang terbaik serta tidak akan menggelapkan dana yang sudah diinvestasikan untuk beberapa proyek yang telah disepakati. Rasa saling percaya yang tinggi akan menumbuhkan nilai yang tinggi dan juga meningkatkan nilai perusahaan dari para stakeholder.

Dalam pengambilan keputusan manajemen selanjutnya juga berdampak terhadap niali perusahaan yaitu kebijakan hutang. Kebijakan hutang ialah kewenangan yang diberikan oleh pemegang saham kepada manajemen perusahaan agar memaksimumkan kesejahteraan para pemegang saham tersebut agar nilai perusahaan tersebut meningkat. Hutang merupakan sesuatu instrument yang sangat sensitif yang bisa mempengaruhi nilai perusahaan. Biasanya para pemilik perusahaan menciptakan hutang pada saat waktu tertentu untuk menaikkan nilai perusahaan. (Utomo, 2009)

Selain hal itu nilai perusahaan juga dipengaruhi oleh peluang pertumbuhan (growth opportunity) yang dimiliki oleh perusahaan. Sriwardany (2006) dalam Pangulu dan Maski (2014) mengatakan bahwa pertumbuhan perusahaan berpengaruh langsung dan bernilai positif terhadap perubahan harga saham. Yang artinya mengenai segala informasi tentang adanya pertumbuhan perusahaan disambut baik oleh investor, 
hal tersebut akan meningkatkan harga saham dan selanjutnya harga saham akan berpengaruh positif terhadap niali perusahaan.

Berdasarkan latar belakang di atas maka masalah yang akan menjadi pokok pembahasan adalah:

1. Apakah tax avoidance berpengaruh terhadap nilai perusahaan?

2. Apakah corporate governance index berpengaruh terhadap nilai perusahaan?

3. Apakah kebijakan hutang berpengaruh terhadap nilai perusahaan?

4. Apakah growth opportunity berpengaruh terhadap nilai perusahaan?

Semua penelitian pasti mempunyai tujuan tertentu begitu juga dengan penelitian ini berdasarkan latar belakang di atas, maka tujuan dan rumusan masalah tersebut adalah untuk mengetahui:

1. Untuk mengetahui pengaruh tax avoidance terhadap nilai perusahaan

2. Untuk mengetahui pengaruh corporate governance index terhadap nilai perusahaan

3. Untuk mengetahui pengaruh kebijakan hutang terhadap nilai perusahaan

4. Untuk mengetahui pengaruh growth opportunity terhadap nilai perusahaan

\section{Tinjauan Pustaka}

\section{Tax Avoidance}

Tax avoidance merupakan tindakan penghematan pajak yang masih dalam koridor perundang - undangan (lawful fashion), dalam teori tradisional tax avoidance dianggap sebagai aktivitas untuk menstransfer kesejahteraan dari Negara kepada pemegang saham (Kim et .al ; 2011).

Tax avoidance merupakan suatu proses transaksi yang berguna untuk meminimalkan jumlah beban pajak yang dibayarkan dengan memanfaatkan kelemahan-kelemahan (loopholes) dengan ketentuan perpajakan yang telah diatur oleh undang-undang sehingga manajemen pajak bisa dikatakan legal karena tidak melanggar tidak melanggar peraturan (Darussalam, 2009).

Hanlon dan Slemord (2009) menguji bagaimana reaksi pasar terhadap tindakan tax avoidance yang dilakukan oleh perusahaan.dari hasil tersebut menyatakan bahwa tindakan melakukan penghindaran pajak (tax avoidance) dapat menurunkan dan juga dapat meningkatkan nilai perusahaan.

Selain perumusan penghindaran pajak yang teknis yang membutuhkan waktu lama, peghindaran pajak juga harus dilakukan dengan teliti dan benar, karena 
penghndaran pajak merupakan hal yang sensitif. Penghindaran pajak dapat mengurangi biaya dan akan meningkatkan nilai dari perusahaan. Namun disisi lain pemegang saham dianggap tidak mendapatkan nilai tambah dari aktifitas penghindaran pajak, karena ada hubungan positif antara penghindaran dan rent diversion (Desai dan Dharmala, 2006) dalam (Brian dan Martani, 2014).

\section{Good Corporate Governance}

Daniri, Ketua Komite Nasional Kebijakan Governance (KNKG) menyatakan bahwa Good Corporate Governance (GCG) ialah sebuah sistem yang mengatur dan mengendalikan perusahaan yang berguna untuk menciptakan nilai tambah (value added) untuk para stakeholder. Indikator penerapan good corporate governance di Indonesia dapat digunakan pada hasil corporate governance perpection index (CGPI) yang dikeluarkan oleh The Indonesian Institue For Corporate Governance (IICG) dan laporan tersebut dipublikasikan oleh majalah SWA.

Corporate Governance Perpection Index (CGPI) merupakan program riset dan pemeringkatan penerapan pada good corporate governance (GCG) pada perusahaanperusahaan yang terdapat di Indonesia melalui riset perancangan yang berguna untuk mendorong perusahaan untuk meningkatkan kualitas konsep corporate governance( $\mathrm{CG}$ ) dengan cara perbaikan yang saling berhubungan dengan melakukan evaluasi dan bencmarking.

Good corporate governance menjadi upaya untuk dapat mengelola resiko bagi perusahaan yang signifikan, tujuanya untuk memenuhi tujuan bisnisnya dengan cara pengamanan asset dan meningkatkan nilai investasi bagi pemegang saham dalam waktu jangka yang panjang (Effendi, 2009).

\section{Kebijakan Hutang}

Kebijakan hutang diukur dengan menggunakan Debt to Equity Rasio.Debt to Equity Rasio merupakan perbandingan antara total hutang dengan total modal sendiri. Total hutang yaitu total total kewajiban yang harus dibayar oleh perusahaan baik dalam waktu jangka panjang maupun jangka pendek.Jika Debt to Equity Ratio makin tinggi maka akan menunjukkan besarnya modal pinjaman yang akan digunakan sebagai pembiayaan aktiva perusahaan dan juga kegiatan operasional perusahaan (Brigham dan Houston, 2006). 


\section{Growth Opportunity}

Growth opportunity merupakan peluang pertumbuhan pada suatu perusahaan dimasa yang akan datang (Mai, 2006 dalam Hermuningsih, 2013). Perusahaanperusahaan yang memprediksi akan mengalami peluang pertumbuhan yang tinggi dimasa depan akan memilih menggunakan saham sebagai pendanaan untuk kegiatan operasional perusahaan. Dengan adanya hal tersebut perusahaan yang memiliki pertumbuhan yang rendah akan lebih memilih untuk menggunakan hutang jangka panjang. (Sriwardany dalam Pangulu dan Maski, 2014). Menyatakan bahwa pertumbuhan pada perusahaan mempunyai pengaruh positif dan secara langsung mempengaruhi perubahan harga saham.

\section{Nilai Perusahaan}

Jika harga di pasar tinggi maka nilai perusahaan jugaakan tinggi, nilai perusahaan yang tinggi diikuti oleh tingginya tingkat kemakmuran oleh pemegang saham. (Husnan, 2000), jika nilai perusahaan tinggi menjadikan keinginan para pemilik perusahaan karena dengan adanya nilai perusahaan yang tinggi akan menunjukan nilai baik dan menunjukan tingkat kemakmuran pemegang saham juga tinggi. Ketika nilai perusaahaan tinggi maka membuat pasar percaya kalau perusahaan tersebut bisa dikatakan maju dan semakin percaya pada kinerja perusahaan saat ini maupun dimasa yang akan datang.

Menurut Husnan (2000) definisi nilai perusahaan adalah harga yang dibayar oleh calon pembeli apabila perusahaan tersebut dijual, sedangkan menurut Martin, et al (2000) mengemukakan nilai perusahaan adalah nilai atau harga dipasaran yang berlaku atas saham umum yang beredar pada perusahaan.

Nilai perusahaan memberikan kesejahteraan bagi pemegang saham secara maksimum jika harga saham pada perusahaan meningkat.Semakin tinggi harga sahamnya maka semakin tinggi juga kesejahteraan pemegang saham tersebut (Sari, 2010).

\section{Kerangka Pemikiran}

Dari beberapa uraian di atas penelitian ini terdapat dua variabel yang digunakan yaitu independen dan dependen yaitu:

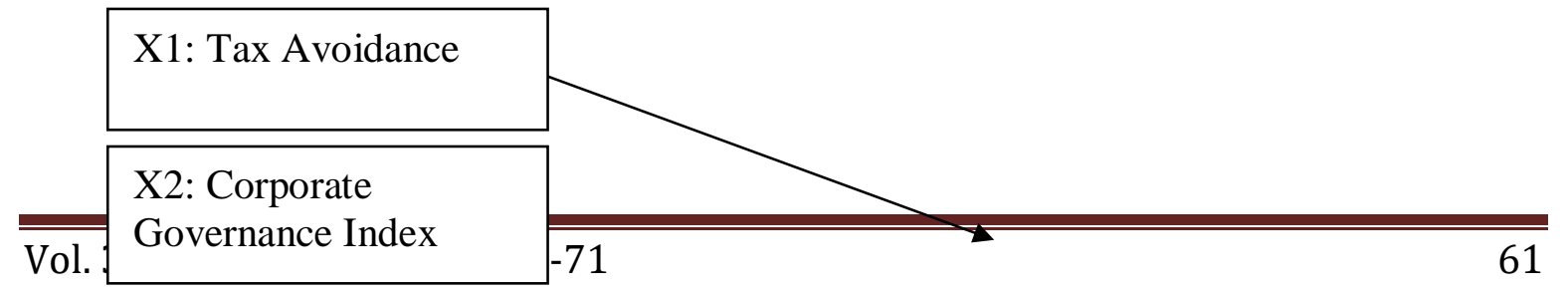




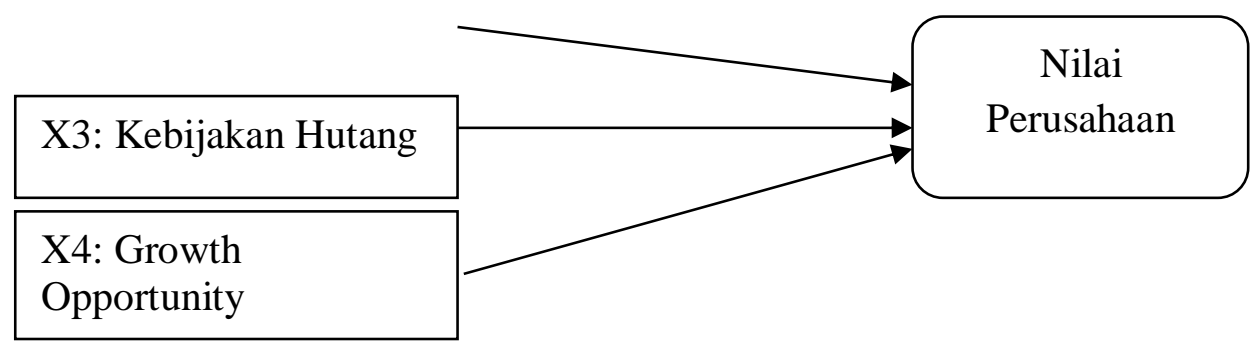

\section{Gambar 1. Kerangka Pemikiran}

\section{Pengembangan Hipotesis Penelitian}

Berdasarkan rumusan masalah yang telah dijelaskan maka ada beberapa pengembangan hipotesis dari penelitian ini:

Tax avoidance merupakan tindakan pengurangan pajak yang dilakukan oleh manajemen perusahaan, hal ini sebanding dengan penelitian Desai dan Dharmapala.(2009), yang melakukan pengujian cross sectional dimana kepemilikan institusional berpengaruh pada tax avoidance dengan nilai perusahaan. Perusahaan pada kepemilikan institusional akan lebih kuat, tax avoidance berpengaruh terhadap nilai perusahaan. Maka ini menunjukkan bahwa pengaruh pemegang saham perusahaan tergantung pada kemampuan pemegang saham dalam mngontrol manajemen perusahaanmembuktikan bahwa transparasi perusahaan berpengaruh terhadap tindakan tax avoidance yang dilakukan, hasil dari penelitian menemukan bahwa tax avoidance mempengaruhi nilai perusahaan, terutama untuk perusahaan yang transparasinya baik, Dyreng, et.al (2008). Maka diajukan hipotesis sebagai berikut:

\section{H1: Tax avoidance berpengaruh signifikan terhadap nilai perusahaan}

Siallagan dan Machfoedz (2006) dalam penelitian membuktikan bahwa mekanisme corporate governance terdiri dari kepemilikan manajerial dan komite audit berpengaruh positif terhadap kualitas laba perusahaan. pada mekanisme corporate governance (kepemilikan manajerial, dewan komisaris dan komite audit) positif berpengaruh terhadap nilai perusahaan. Maka diajukan hipotesis sebagai berikut:

\section{H2: Corporate Governance Index berpengaruh signifikan terhadap nilai perusahaan}

Mulianti (2010) membuktikan bahwa ukuran pada perusahaan berpengaruh positif terhadap kebijakan hutang. Begitu juga dengan variabel risiko bisnis mempunyai pengaruh negatif terhadap kebijakan hutang. Sedangkan pada variabel 
likuiditas mempunyai pengaruh positif dan tidak signifikan terhadap kebijakan hutang karena nilainya melebihi dari taraf signifikan.Kebijakan hutang berpengaruh terhadap nilai perusahaan.

Ulya (2014) Membuktikan bahwa kebijakan dividen dan kebijakan hutang mempunyai hubungan yang saling berhubungan dan mempunyai hubungan positif, signifikan terhadap nilai perusahaan sedangkan pada variabel profitabilitas, kinerja perusahaan dan keputusan investasi berpengaruh positif terhadap nilai perusahaan. Maka diajukan hipotesis sebagai berikut:

\section{H3: Kebijakan Hutang berpengaruh signifikan terhadap nilai perusahaan}

Hermuningsih (2013) membuktikan variabel profitabilitas, growth opportunity dan struktur modal, mempunyai pengaruh positif dan signifikan terhadap nilai perusahaan.maka semakin besar profitabilitas semakin besar peluang pertumbuhan. Dengan demikian nilai perusahaan juga makin tinggi.Kedua variabel tersebut yaitu struktur modal adalah variabel intervening bagi growth opportunity dan tidak untuk profitabilitas, karena variabel profitabilitas memiliki pengaruh yang tidak searah atau berlawanan dengan struktur modal. Hal ini berarti struktur modal akan mempunyai pengaruh profitabilitas yang positif besar terhadap nilai perusahaan. Maka diajukan hipotesis sebagai berikut:

\section{H4: Growth Opportunity berpengaruh signifikan terhadap nilai perusahaan}

\section{METODOLOGI PENELITIAN}

\section{Jenis dan Sumber Data}

Jenis data yang digunakan pada penelitian ini adalah data kuantitatif, yaitu perusahaan yang mengikuti Corporate Governance Perpection Index pada tahun 2015-2017 yang terdaftar di Bursa Efek Indonesia, data tersebut diperoleh dari website www.idx.com dan majalah SWA.

Sumber data yang digunakan dalam penelitian ini adalah data sekunder, yaitu data yang diperoleh dari peneliti dari pihak kedua atau pihak ketiga yang dibuat oleh perusahaan dan laporan tersebut sudah diaudit.

\section{Populasi, Sampel, Ukuran Sampel dan Teknik Pengambilan Sampel}

Populasi dalam penelitian ini adalah perusahaan yang terdaftar di Bursa Efek Indonesia pada tahun 2015-2017 dan perusahaan yang mengikuti Corporate Governance Perpection Index 
Metode yang digunakan adalah purposive sampling yaitu memilih sampel sesauai dengan kriteria yang dibutuhkan. Adapun criteria dan jumlah sampel dalam penelitian ini adalah sebagai berikut:

Tabel 1. Teknik Pengambilan Sampel

\begin{tabular}{|l|c|}
\hline \multicolumn{1}{|c|}{ Jenis Kriteria } & Jumlah \\
\hline $\begin{array}{l}\text { Perusahaan yang masuk dalam Corporate Governance } \\
\text { Index pada tahun 2015-2017 }\end{array}$ & 72 \\
\hline $\begin{array}{l}\text { Perusahaan peserta CGPI yang tidak terdaftar di Bursa } \\
\text { Efek Indonesia }\end{array}$ & $(55)$ \\
\hline $\begin{array}{l}\text { Peusahaan tidak mengalami kerugian selama tahun } \\
\text { penelitian }\end{array}$ & 0 \\
\hline Laporan keuangan disajikan dalam mata uang rupiah & 0 \\
\hline $\begin{array}{l}\text { Perusahaan yang memenuhi kriteria untuk } \\
\text { dijadikan sampel }\end{array}$ & $\mathbf{1 7}$ \\
\hline
\end{tabular}

\section{Metode Pengolahan Data Penelitian}

Metode analisis data yang digunakan dalam penelitian ini adalah analisis regresi linier berganda. Dengan persamaan sebagai berikut:

$\mathrm{PBV}=\mathrm{a}+\mathrm{B}_{1} \mathrm{ETR}_{\mathrm{it}}+\mathrm{B}_{2} \mathrm{CGI}_{\mathrm{it}}+\mathrm{B}_{3} \mathrm{DER}+\mathrm{B}_{4} \mathrm{GRW}+\mathrm{e}$

Keterangan:

a

: Konstanta

PBV

: Nilai perusahaan yang diukur dengan PBV

ETR : Tarif pajak efektif perusahaan pada perusahaan tahun $\mathrm{t}$

CGI : Skor CG perusahaan pada tahun $\mathrm{t}$

DER : Dept to Equity Ratio perusahaan pada tahun $\mathrm{t}$

GRW : Growth Opportunity perusahaan pada tahun t

\section{HASIL PENELITIAN DAN PEMBAHASAN}

Penelitian menggunakan data sekunder artinya data yang diperoleh oleh peneliti dari pihak kedua atau dari pihak ketiga. Data yang digunakan dalam penelitian ini adalah Tax Avoidance, Corporate Governance Index, Kebijakan Hutang, Growth Opportunity dan Nilai Perusahaan. data tersebut diperoleh dari www.idx.com dan majalah SWA yang dilakukan oleh The Indonesia InstituteFor Corporate Governance (IICG) pada tahun 2015-2017.

\subsection{Deskripsi Variabel}

Variabel Dependen 
Variabel dalam penelitian ini adalah nilai perusahaan yang diukur dengan menggunakan rasio pasar yaitu price book value (PBV). (Weston dan Brigham, 2001:92).

$$
\mathrm{PBV}=\frac{\text { market } \text { price pershare }}{\text { book value perhare }}
$$

Dimana:

Market Price Per Share : Harga pasar saham (harga saham penutupan)

Book Value Per Share : Total Ekuitas dibagi dengan jumlah saham yang beredar

\section{Variabel Independen}

\section{Tax Avoidance}

Suatu skema transaksi yang ditujukan untuk meminimalisir pembayaran pajak dengan memanfaatkan kelemahan-kelemahan sesuai dengan ketentuan perpajakan yang berlaku, Tax avoidance dapat diukur dengan Long Run ETR.Yang diukur dengan Long Run ETR. Penelitian Long run ETR ialah metode yang dikembangkan oleh Dyreng et.al. (2008) dalam (Brian dan Martani, 2014).

$$
\text { CASH ETR }_{\text {it }}=\frac{\text { CashTaxPaidit }}{\text { Pretax Income it }}
$$

Cash ETR it : Pengukuran tax avoidance pada perusahaan $\mathrm{t}$

Cash Tax Paid it : Pajak yang dibayarkan perusahaan secara kas pada tahun $\mathrm{t}$ (terdapat dalam laporan arus kas perusahaan)

Pretax Income it : Laba perusahaan sebelum pajak pada tahun $\mathrm{t}$

\section{Corporate Governance Index}

Variabel ini diukur menggunakan instrument yang dikembangkan oleh Indonesian of Corporate Governance (IICG) yang berupa Corporate GovernancePrepectin Index (CGPI) yang terbit di majalah SWA, CGPI adalah berisi skor hasil survey mengenai penerapan corporate governance pada perusahaanperusahaan yang tercatat di Bursa Efek Indonesia. (Lilik Sulistiyana, Nur Diyan, 2013)

Tabel 1. Pemeringkatan CGPI

\begin{tabular}{l|l} 
Skor CGPI & Rating
\end{tabular}




\begin{tabular}{|l|l|}
\hline $85,00-100$ & Sangat Terpercaya \\
\hline $70,00-84,99$ & Terpercaya \\
\hline $55,00-69,99$ & Cukup Terpercaya \\
\hline
\end{tabular}

Sumber : Majalah SWA Edisi 27 Tahun 2012

\section{Kebijakan Hutang}

Kebijakan Hutang menurut Djarwanto (2004:34) adalah kewajiban perusahaan untuk membayar sejumlah uang atau jasa atau menyerahkan barang pada tanggal tertentu kepada pihak lain. Hutang merupakan salah satu pembiayaan bersifat eksternal yang digunakan perusahaan untuk membiayai aktivitas operasional. Sebelum pihak manajemen mengambil keputusan untuk mengambil hutang maka harus mempertimbangkan besarnya bunga yang akan menyebabkan semakin meningkatnya leverage keuangan perusahaan.Pengukuran pada kebijakan hutang dapat diukur dengan menggunakan perbandingan antara hutang dibagi dengan total ekuitas, DER yaitu rasio besarnya modal sendiri yang dijadikan sebagai jaminan hutang.(Yustitianingrum, IY, 2013) dengan rumus:

$$
\text { DER }=\frac{\text { Total Hutang }}{\text { Total Ekuitas }}
$$

DER : Rasio yang digunakan untuk mengukur tingkat solvabilitas perusahaan

Total Hutang $\quad$ : Total hutang jangka pendek dan jangka panjang

Total Ekuitas : Total modal pada perusahaan

\section{Growth Opportunity}

Growth Opportunity merupakan peluang pertumbuhan suatu perusahaan di masa yang akan datang. Suatu prusahaan yang mempunyai laju pertumbuhan yang tinggi harus mempunyai modal yang besar untuk membiayai seumua aktivitas operasional perusahaan. (Arif, 2015)

Menurut Huang (2005) growth opportunity dihitung dengan rumus:

GRW $=\frac{\text { Total Asset Tahunt-Total Asset Tahunt }-1}{\text { Total Asset Tahun } \mathrm{t}}$ 


\subsection{Analisis Data}

\section{Analisis Regresi Linier Berganda}

Analisis regresi linier berganda digunakan untuk meneliti faktor-faktor yang berpengaruh antara variabel independen terhadap variabel dependen, dimana variabel independen yang digunakan dalam penelitian ini lebih dari satu.

Tabel 3. Analisis Regresi Linier Berganda

\begin{tabular}{|l|r|r|r|}
\hline \multicolumn{1}{|c|}{ Coefficients $^{\mathbf{a}}$} \\
\cline { 2 - 4 } Model & \multicolumn{1}{|c|}{ Unstandardized Coefficients } & $\begin{array}{c}\text { Standardized } \\
\text { Coefficients }\end{array}$ \\
\cline { 2 - 4 } 1(Constant) & $-4.217 \mathrm{E} 6$ & \multicolumn{1}{c|}{ Std. Error } & \multicolumn{1}{c|}{ Beta } \\
ETR & $-3.088 \mathrm{E} 6$ & $1.083 \mathrm{E} 6$ & -.355 \\
CGI & 72616.004 & 28012.013 & .341 \\
DER & 34953.903 & 46195.245 & .100 \\
GWR & -69440.894 & $1.539 \mathrm{E} 6$ & -.006 \\
\hline
\end{tabular}

a. Dependent Variable: PBV

PBV $=$ - 4,217E6- 3,088E6 ETR + 72616,004 CGI + 34953,903 DER - 69440,894

GWR

Hasil persamaan regresi tersebut menunjukkan bahwa koefisien regresi variabel CGI dan DER bertanda positif. Hal ini menunjukkan bahwa peningkatan CGI dan DER akan meningkatkanPBV. Sedangkan koefisien regresi variabel ETR dan GWR bertanda negatif. Hal ini menunjukkan bahwa peningkatan ETR dan GWR akan menurunkanPBV.

\subsection{Pengujian Hipotesis}

\section{Uji t}

Uji t digunakan untuk mengetahui apakah ada pengaruh yang signifikan secara parsial variabel ETR, CGI, DER dan GWR terhadap PBV.Hasil Uji t dapat dilihat dari tabel Coefficients pada olahan data SPSS.

\section{Tabel 4. Uji t}

Coefficients $^{\mathrm{a}}$

\begin{tabular}{|c|c|c|c|c|c|}
\hline \multirow[b]{2}{*}{ Model } & \multicolumn{2}{|c|}{ Unstandardized Coefficients } & \multirow{2}{*}{$\begin{array}{c}\begin{array}{c}\text { Standardized } \\
\text { Coefficients }\end{array} \\
\text { Beta }\end{array}$} & \multirow[b]{2}{*}{$\mathrm{T}$} & \multirow[b]{2}{*}{ Sig. } \\
\hline & B & Std. Error & & & \\
\hline $1 \quad$ (Constant) & $-4.217 \mathrm{E} 6$ & 2.300E6 & & -1.833 & .073 \\
\hline ETR & $-3.088 E 6$ & 1.083E6 & -.355 & -2.852 & .006 \\
\hline CGI & 72616.004 & 28012.013 & .341 & 2.592 & .013 \\
\hline DER & 34953.903 & 46195.245 & .100 & .757 & .453 \\
\hline
\end{tabular}




\begin{tabular}{l|lllll|}
\hline GWR & -69440.894 & $1.539 \mathrm{E} 6$ & -.006 & -.045 & .964 \\
\hline a. Dependent Variable: PBV
\end{tabular}

\section{Koefisien Determinasi}

Koefisien determinasi digunakan untuk mengukur seberapa jauh atau seberapa persen kemampuan variabel independen berpengaruh terhadap variabel dependen. Pengujiannya dapat dilihat di tabel Model Summary pada Adjustd Rsquare. Hasil yang diperoleh sebagai berikut:

\section{Tabel 5. Uji Koefisien Determinasi}

\begin{tabular}{|c|c|c|c|}
\hline \multicolumn{4}{|c|}{ Model Summary ${ }^{b}$} \\
\hline Model & $\mathrm{R}$ & R Square & $\begin{array}{l}\text { Adjusted R } \\
\text { Square }\end{array}$ \\
\hline 1 & $.553^{\mathrm{a}}$ & .305 & .245 \\
\hline
\end{tabular}

Artinya sebanyak 24,5\% variabel ETR, CGI, DER dan GWR mempengaruhi variabel PBV sedangkan sisanya dipengaruhi faktor lain yang tidak diteliti dalam penelitian ini.

\subsection{Pembahasan}

Penelitian ini dimaksudkan untuk mengetahui pengaruh Tax Avoidance, Corporate Governance Index, Kebijakan Hutang dan Growth Opportunity terhadap nilai perusahaan. berdasarkan hasil pengujian Spss yang telah dilakukan, ada beberapa hipotesis sebagai berikut:

1. Pada Uji t diperoleh hasil:

a. Tax Avoidance (ETR) terhadap Nilai Perusahaan (PBV)

Hasil analisis ETR terhadap PBV adalah varibel ETR secara parsial berpengaruh terhadap variabel PBV karena dalam tabel Coefficients nilai signifikan variabel ETR $(0,006)$ lebih kecil dari $\alpha(0,05)$.Hasil penelitian ini tidak sejalan dengan penelitian yang dilakukan oleh Chasbiandani dan Martani (2012) dan Simartama(2014) yang menyatakan tidak adanya pengaruh tax avoidance terhadap nilai perusahaan. Hasil penelitian menemukan bahwa tax avoidance mempengaruhi pengaruh terhadap nilai perusahaan terutama untuk perusahaan yang transparasinya baik.Artinya bahwa transparasi perusahaan berpengaruh terhadap tindakan tax avoidance yang dilakukan.Dyreng,et.al (2008). 
b. Corporate Governance Index (CGI) terhadap Nilai perusahaan(PBV)

Hasil analisis CGI terhadap PBV adalah varibel CGI secara parsial berpengaruh terhadap variabel PBV karena dalam tabel Coefficients nilai sig variabel CGI $(0,013)$ lebih kecil dari $\alpha(0,05)$. Hasil penelitian ini sejalan dengan penelitian Ni Wayan Rustiarini (2010) yang menyatakan bahwa corporate governance index mempunyai pengaruh terhadap nilai perusahaan. ada beberapa hal yang membuat CGI berpengaruh tehadap nilai perusahaan yaitu :

$>$ Tingginya kesadaran perusahaan untuk mengikuti CGC bagaikan kebutuhan, bukan hanya sebagai formalitas

> Manajemen perusahaan tertarik manfaat jangka panjang penerapan CGC

$>$ Meningkatkan kepemilikan saham oleh manajemen dan investor

c. Kebijakan Hutang (DER) terhadap Nilai Perusahaan (PBV)

Hasil analisis DER terhadap PBV adalah varibel DER secara parsial tidak berpengaruh terhadap variabel PBV karena dalam tabel Coefficients nilai sig variabel DER $(0,453)$ lebih besar dari $\alpha(0,05)$. Penelitian ini sejalan dengan Sujoko dan Soebiantoro (2007) yang menyatakan semakin besar hutang maka semakin besar kemungkinan perusahaan tidak mampu membayar kewajiban berupa bunga dan biaya pokok. Maka resiko kebangkrutan akan semakin tinggi. Karena bunga akan meningkat lebih tinggi daripada penghematan pajak.

d. Growth opportunity (GWR) terhadap Nilai Perusahaan (PBV)

Hasil analisis GWR terhadap PBV adalah varibel GWR secara parsial tidak berpengaruh terhadap variabel PBV karena dalam tabel Coefficients nilai sig variabel GWR $(0,964)$ lebih besar dari $\alpha(0,05)$. Hasil penelitian ini sejalan dengan penelitian Wardani (2013). Growth opportunity tidak memoderisasi pengaruh pengungkapan CSR pada nilai perusahaan sehingga didalam hubungan antara CSR dan nilai perusahaan disebabkan karena perusahaan dengan growth opportunity yang tinggi lebih banyak membutuhkan modal yang besar.

2. Koefisien korelasi diperoleh hasil nilai Adjusted R-Square sebesar 0,245 artinya sebesar 24,5\% variabel ETR, CGI, DER dan GWR mempengaruhi variabel PBV, sedangkan sisanya $75,5 \%$ dipengaruhi oleh variabel lainnya. 


\section{[ACCOUNTING GLOBAL JOURNAL] E ISSN 2623-1778}

\section{KESIMPULAN DAN SARAN}

\section{Kesimpulan}

Penelitian ini dimaksudkan untuk mengetahui pengaruh Tax Avoidance, Corporate Governance Index, Kebijakan Hutang dan Growth Opportunity terhadap nilai perusahaan.

1. Tax Avoidance terhadap Nilai Perusahaan. Hasil analisis Tax Avoidance secara parsial berpengaruh terhadap variabel Nilai Perusahaan.

2. Corporate Governance Index terhadap Nilai Perusahaan. Hasil analisis variabel Corporate Governance Index secara parsial berpengaruh terhadap variabel Nilai Perusahaan.

3. Kebijakan Hutang terhadap Nilai Perusahaan. Hasil analisis variaabel Kebijakan Hutang secara parsial tidak berpengaruh terhadap variabel Nilai Perusahaan.

4. Growth Opportunity terhadap Nilai Perusahaan. Hasil analisis variabel Growth Opportunity secara parsial tidak berpengaruh terhadap variabel Nilai Perusahaan.

\section{Saran}

1. Bagi Investor

Bagi investor supaya dapat menggunakan penelitian ini untuk mengetahui pengaruh tax avoidance, corporate governance index, kebijakan hutang dan growth opportunity terhadap nilai perusahaan pada manufaktur dan perbankan yang terdaftar di Bursa Efek Indonesia (BEI) tahun 2013 sampai 2015. Sehingga dapat menjadi pertimbagan dalam pengambilan keputusan.

2. Bagi penelitian selanjutanya

Sebanyak 24,5\% variabel Tax Avoidance, Corporate Governance Index, Kebijakan Hutang dan Growth Opportunity mempengaruhi variabel Nilai Perusahaan sedangkan sisanya dipengaruhi faktor lain yang tidak diteliti dalam penelitian ini. Untuk penelitian selanjutnya agar menambah periode pengamatan yang lebih panjang lagi dan menambah variabel lagi supaya hasil yang diperoleh menjadi lebih luas. 


\section{DAFTAR PUSTAKA}

Brian, I. dan Martani, D. 2014. "Analisis Pengaruh Penghindaran Pajak dan Kepemilikan Keluarga Terhadap Waktu Pengumuman Laporan Keuangan Perusahaan."

Chasbiandani, T. dan Martani, D. 2013. "Pengaruh Tax Avoidance Jangka Panjang Terhadap Nilai Perusahaan".

D., Retno D.R dan Priantinah. 2012. "Pengaruh Good Corporate Social Responsibility terhadap Nilai Perusahaan." Jurnal Nominal, : Volume 1 Nomor 1.

Hanlon, M. dan Heitzman, S. 2010. "A Review of Tax Research". Journal of Accounting and Economies: $127-178$.

Herdiyanto, D.G. 2015. "Pengaruh Tax Avoidance Terhadap Nilai Perusahaan".

Lilik, Sulistiyana, dan Nur, D. 2015. "Pengaruh Tax Avoidance, Corporate Governance Index, Kebijakan Hutang dan Growth Opportunity terhadap Nilai Perusahaan".

Mardiasmo. 2009. "Perpajakan Edisi Revisi". Yogyakarta.

Muhammad, Z. 2005. "Manajemen Perpajakan". Salemba. Jakarata

Muhyarsyah. 2007. "Pengaruh Kebijakan Hutang Terhadap Nilai Perusahaan" Jurnal Riset Akuntansi dan Bisnis, : Vol. 7 No. 2.

Oktavia dan Martani, D. 2013. "Tingkat Pengungkapan dan Penggunaan Derivatif Keuangan Dalam Aktivitas Penghindaran Pajak". Vol 10, No. 2.

Pangulu, A.S. 2014. "Pengaruh Profitabilitas, Growth Opportunity dan Struktur Modal Terhadap Nilai Perusahaan". Universitas Brawijaya.

Partha, G. A dan Noviari, N. 2016. "Pengaruh Penghindaran Pajak Jangka Panjang Pada Nilai Perusahaan dengan Transparasi Informasi sebagai Variabel Pemoderisasi". EJurnal Akuntansi Universitas Udanaya. No 14.3.

Rahmadi, U. 2000. "Hukum Ekonomi dalam Dinamika". Djambatan. Jakarta.

Sari, I. A. 2009. "Pengaruh Kebijakan Diversifikasi Usaha terhadap Kinerja Perusahaan Manufaktur yang Terdaftar di Bursa Efek Indonesia". SOSEKHUM Vol 5 No 7.

Sri, H. 2013. "Pengaruh Profitabilitas, Growth Opportunity, Struktur Modal pada Perusahaan Public di Indonesia". Lecture at Economic Departement, University of Sarjanawiyata.

www.idx.com

Www.iicg.co.id 